\title{
The Consolidation Effect of Fly Ash by the New Curing Agent and Cement and the Environment Safety of Its Application
}

\author{
Yifan Yang ${ }^{1, a}$, Jiaying Sun ${ }^{2, b}$, Liangzhi Lu ${ }^{1, c}$ and Yingbo Jiang ${ }^{2}$ \\ ${ }^{1}$ School of Shanghai University, Shanghai 200072, China \\ ${ }^{2}$ School of Ningbo Institute of Technology, Zhejiang University, Ningbo 315100, China \\ ayyf920806@qq.com, bjakys@163.com, 'luliangzhi@live.cn.com
}

Keywords:fly ash, heavy metal, consolidation, curing agent, asphalt.

\begin{abstract}
This paper makes a comparison of consolidation effect for heavy metals between the new curing agent and cement at first. Then, through experiment, a conclusion can be got that heavy metals' leaching rate which solidified by the new curing agent met related national standard. At the same time, certain mix proportion is determined for certain kind of fly ash. The safety of MSWI fly ash's application to asphalt mixture is be verified.
\end{abstract}

\section{Introduction}

Fly ash is a part of the materials collected from municipal solid waste incineration(MSWI) flue gas by flue gas dust collecting equipment, and it is usually accounts for about 15\% 20\%of the total ash, and the fly ash also contains dioxins [1] and other toxic organic compounds.

At present, there are three approaches for development and application in the incineration fly ash harmless and stable treatment all around the world [2]: 1, secure landfill methods. 2, solidification-steady methods. 3, wet chemical treatment method. Shi Huisheng [3] has studied the curing effect of cement on fly ash. Yu Zhuqing [4] makes MSWI fly ash as the active material added into the cement, and had figured out MSWI fly ash had some impact on water requirement of normal consistency, setting time, strength and the leaching of heavy metal. Therefore, it is necessary to develop a new consolidation agent to fly ash for consolidation [5, 6], and use asphalt to consolidate the fly ash for two times to reduce the heavy metal leaching toxicity, so that heavy metals would have a long-term stability and avoid the secondary pollution for environmental.

\section{Experiment}

\subsection{Raw Materials}

There are three kinds of MSWI fly ash from Ningbo Zhongke Green Electric Co. Ltd. ,Cixi Incineration Plant and Fenglin Incineration Plant in the experiment. Heavy metal content in fly ash is detected by ordinary acid decomposition method (i.e. four acid digestion method) with HJ/T 1662004. Fly ash heavy metals content indicators are shown in Table 1.

Cement is P.O42.5 produced by Zhejiang Sanshi Special Cement Co. Ltd. Glue Sand is produced by Xiamen Aisi standard sand Co. Ltd. according to "China ISO standard sand". The asphalt is 70\# matrix asphalt produced by Sinopec.

A new curing agent is developed mainly by slag and other industrial waste residue and activator composition in this experiment.

Table 1 Heavy Metals Content in Fly Ash(Weight Percent)

\begin{tabular}{cccccccc}
\hline Type of Fly Ash & $\mathrm{Cr}$ & $\mathrm{Cu}$ & $\mathrm{Pb}$ & $\mathrm{Zn}$ & $\mathrm{Cd}$ & $\mathrm{Ni}$ & Units \\
\hline Zhongke & 0.01856 & 0.08386 & 0.03 & 0.309 & 0.00202 & $1.504 \mathrm{E}-05$ & $\mathrm{mg} / \mathrm{L}$ \\
Cixi & 1.554 & 11.8 & 1.247 & 30.45 & 0.209 & 1.182 & $\mathrm{mg} / \mathrm{L}$ \\
Fenglin & 1.005 & 4.421 & 1.938 & 36.71 & 0.892 & 0.371 & $\mathrm{mg} / \mathrm{L}$ \\
\hline
\end{tabular}




\subsection{Leaching Rate Of Heavy Metals Test}

The digestion of solidified fly ash is though "solid waste-Extraction procedure for leaching toxicity-horizontal vibration method"(HJ557-2010).

\section{Experimental Result: Heavy Metal Leaching Rate of Fly Ash Solidified by Cement and The New Curing Agent}

Table 2 shows the leaching rate of fly ash solidified by P.O42.5 cement.

Table 2 28d heavy metal leaching rate of fly ash solidified by cement(Unit: mg/L)

\begin{tabular}{cccccccc}
\hline $\begin{array}{c}\text { Types of } \\
\text { fly ash }\end{array}$ & Cement:Ash & $\mathrm{Cr}$ & $\mathrm{Cu}$ & $\mathrm{Pb}$ & $\mathrm{Zn}$ & $\mathrm{Cd}$ & $\mathrm{Ni}$ \\
\hline \multirow{5}{*}{ ZhongKe } & $1: 1$ & $8.07 \mathrm{E}-02$ & $7.151 \mathrm{E}-03$ & $7.271 \mathrm{E}-03$ & $2.6 \mathrm{E}-02$ & $8.56 \mathrm{E}-04$ & not detected \\
& $1: 1.5$ & 0.326 & $4.429 \mathrm{E}-03$ & $1.085 \mathrm{E}-02$ & $1.9 \mathrm{E}-02$ & $8.83 \mathrm{E}-04$ & not detected \\
& $1: 2$ & 0.1478 & $5.42 \mathrm{E}-04$ & $1.506 \mathrm{E}-03$ & $2 \mathrm{E}-03$ & $1.91 \mathrm{E}-04$ & not detected \\
& $1: 1.5$ & 0.1366 & $5.03 \mathrm{E}-04$ & $1.485 \mathrm{E}-03$ & $6 \mathrm{E}-03$ & $6.45 \mathrm{E}-04$ & not detected \\
$\mathrm{CiXi}$ & $1: 1.5$ & $6.575 \mathrm{E}-02$ & 0.604 & 0.2868 & 0.744 & $1.274 \mathrm{E}-02$ & $1.443 \mathrm{E}-02$ \\
& $1: 2$ & $5.568 \mathrm{E}-02$ & $7.247 \mathrm{E}-03$ & $7.432 \mathrm{E}-03$ & $3.3 \mathrm{E}-02$ & $4.49 \mathrm{E}-04$ & not detected \\
& $1: 2.5$ & $3.917 \mathrm{E}-02$ & $7.251 \mathrm{E}-03$ & $1.031 \mathrm{E}-02$ & $2.4 \mathrm{E}-02$ & $6.32 \mathrm{E}-04$ & not detected \\
& $1: 1$ & 0.479 & 0.157 & 0.1186 & 0.295 & $1.386 \mathrm{E}-02$ & $8.505 \mathrm{E}-03$ \\
FengLin & $1: 1.5$ & 0.721 & 0.323 & 0.534 & 1.466 & $5.905 \mathrm{E}-02$ & $1.388 \mathrm{E}-02$ \\
& $1: 2$ & 1.078 & $1.212 \mathrm{E}-02$ & $1.338 \mathrm{E}-02$ & $6.1 \mathrm{E}-02$ & $9.89 \mathrm{E}-04$ & $1.057 \mathrm{E}-03$ \\
& $1: 2.5$ & 1.192 & $4.303 \mathrm{E}-03$ & $1.942 \mathrm{E}-02$ & $3.6 \mathrm{E}-02$ & $1.425 \mathrm{E}-03$ & $1.18 \mathrm{E}-03$ \\
\hline
\end{tabular}

The proportion of the new curing agent is presented in Table 3. All of the category devided into two kinds that contain $600 \mathrm{~g}$ and $620 \mathrm{~g}$ activator. There are 18 kinds of mixture ratio in total.

Then, the leaching rate of fly ash solidified by the new curing agent is shown in Table 4. Table 3 the proportion of the new curing agent(activator: 600g and 620g)

\begin{tabular}{ccccc}
\hline Types of fly ash & Category & Dosage of fly ash & $\begin{array}{c}\text { Dosage of curing } \\
\text { agent }\end{array}$ & $\begin{array}{c}\text { Dosage of } \\
\text { accelerant }\end{array}$ \\
\hline \multirow{3}{*}{ Ci Xi } & $\mathrm{A}_{1} \mathrm{~B}_{1} \mathrm{C}_{1}$ & 357 & 143 & 2.9 \\
& $\mathrm{~A}_{1} \mathrm{~B}_{2} \mathrm{C}_{2}$ & 300 & 200 & 8.0 \\
\multirow{5}{*}{ Feng Lin } & $\mathrm{A}_{1} \mathrm{~B}_{3} \mathrm{C}_{3}$ & 250 & 250 & 15.0 \\
& $\mathrm{~A}_{2} \mathrm{~B}_{1} \mathrm{C}_{2}$ & 357 & 143 & 5.7 \\
& $\mathrm{~A}_{2} \mathrm{~B}_{2} \mathrm{C}_{3}$ & 300 & 200 & 12.0 \\
\multirow{3}{*}{ ZhongKe } & $\mathrm{A}_{2} \mathrm{~B}_{3} \mathrm{C}_{1}$ & 250 & 250 & 5.0 \\
& $\mathrm{~A}_{3} \mathrm{~B}_{1} \mathrm{C}_{3}$ & 357 & 143 & 8.6 \\
& $\mathrm{~A}_{3} \mathrm{~B}_{2} \mathrm{C}_{1}$ & 300 & 200 & 4.0 \\
& $\mathrm{~A}_{3} \mathrm{~B}_{3} \mathrm{C}_{2}$ & 250 & 250 & 10.0 \\
\hline
\end{tabular}

\section{Analysis and Discussion: The Effect Analysis and Comparisonof Heavy Metals' Consolidation in Fly Ash by Cement and New Curing Agent}

The curing rate of cement and new curing agent for metal $\mathrm{Cr}$ can be seen in Fig. 1. The mix proportion one to six of the new curing agent correspondA3B2C1(620g), A3B2C1(600g), A3B3C2(620g), A3B3C2(600g), A3B1C3(620g), A3B1C3(600g) of ZhongKe; A1B2C2(620g), A1B2C2(600g), A1B1C1(620g), A1B1C1(600g), A1B3C3(620g), A1B3C3(600g) of CiXi and A2B2C3(620g), A2B2C3(600g), A2B1C2(620g), A2B1C2(600g), A2B3C1(620g), A2B3C1(600g) of FengLin. The mix proportions in the following histogram are all the same as mentioned above. Fig. 1 indicates that the curing effect of new curing agent is better than cement. And, the new curing agent's curing effect for metal $\mathrm{Cr}$ in ZhongKe and FengLin is obviously better than cement's. As for CiXi fly ash, the proportionsA1B2C2(600g), A1B3C3 (620G) and A1B3C3(600g) have good solidification effect when cured by the new curing agent. However, if using cement, the curing rate of Cr will be only 0.940697 when the mix cement:ash is 1:2.5. 
Table 4 28d heavy metal leaching rate of fly ash solidified by the new curing agent (Unit: mg/L)

\begin{tabular}{|c|c|c|c|c|c|c|c|}
\hline $\begin{array}{l}\text { Types of } \\
\text { fly ash }\end{array}$ & Proportioning & $\mathrm{Cr}$ & $\mathrm{Cu}$ & $\mathrm{Pb}$ & Zn & $\mathrm{Cd}$ & $\mathrm{Ni}$ \\
\hline \multirow{6}{*}{ ZhongKe } & A3B2C1(620g) & $1.421 \mathrm{E}-02$ & $1.114 \mathrm{E}-02$ & 6.195E-03 & 2.3E-02 & $6.59 \mathrm{E}-04$ & $6.482 \mathrm{E}-03$ \\
\hline & А3В2C1(600g) & $1.122 \mathrm{E}-02$ & 2.012E-02 & 5.729E-03 & $1.4 \mathrm{E}-02$ & 3.76E-04 & not detected \\
\hline & АЗВ3С2(620g) & 3.789E-03 & $1.231 \mathrm{E}-02$ & $7.282 \mathrm{E}-03$ & $1.2 \mathrm{E}-02$ & 4.53E-04 & not detected \\
\hline & АЗВ3С2(600g) & $6.322 \mathrm{E}-03$ & 2.008E-02 & $5.227 \mathrm{E}-03$ & $1.3 \mathrm{E}-02$ & 3.16E-04 & $1.063 \mathrm{E}-03$ \\
\hline & А3B1C3(620g) & $1.402 \mathrm{E}-02$ & $1.279 \mathrm{E}-02$ & 1.073E-02 & 1.7E-02 & $1.018 \mathrm{E}-03$ & not detected \\
\hline & АЗВ1C3(600g) & $1.209 \mathrm{E}-02$ & $1.453 \mathrm{E}-02$ & 8.087E-03 & $1 \mathrm{E}-02$ & 6.11E-04 & not detected \\
\hline \multirow{6}{*}{ Ci Xi } & A1B2C2(620g) & 0.3558 & 2.419E-02 & $1.6 \mathrm{E}-02$ & 3.4E-02 & $1.861 \mathrm{E}-03$ & 8.867E-03 \\
\hline & A1B2C2(600g) & 8.456E-02 & $2.166 \mathrm{E}-02$ & $9.399 \mathrm{E}-03$ & 2.1E-02 & 2.523E-03 & 4.431E-03 \\
\hline & A1B1C1(620g) & 0.5575 & $2.436 \mathrm{E}-02$ & 1.677E-02 & 2.2E-02 & $2.292 \mathrm{E}-03$ & not detected \\
\hline & A1B1C1(600g) & 0.2552 & $1.294 \mathrm{E}-02$ & $1.148 \mathrm{E}-02$ & 2.3E-02 & 2.177E-03 & not detected \\
\hline & A1B3C3(620g) & $2.768 \mathrm{E}-02$ & $1.014 \mathrm{E}-02$ & 8.557E-03 & $1.5 \mathrm{E}-02$ & 7.25E-04 & not detected \\
\hline & A1B3C3(600g) & 4.457E-02 & 1.162E-02 & 9.393E-03 & 2.5E-02 & $1.084 \mathrm{E}-03$ & not detected \\
\hline \multirow{7}{*}{ Feng Lin } & A2B2C3(620g) & 0.1528 & $1.069 \mathrm{E}-02$ & $2.281 \mathrm{E}-02$ & 2.2E-02 & $4.144 \mathrm{E}-03$ & not detected \\
\hline & A2B2C3(600g) & 5.993E-02 & $1.056 \mathrm{E}-02$ & 2.2E-02 & $1.5 \mathrm{E}-02$ & 3.317E-03 & not detected \\
\hline & A2B1C2(620g) & 0.16 & 1.229E-02 & $2.341 \mathrm{E}-02$ & 2.5E-02 & 4.615E-03 & not detected \\
\hline & & & & & & & \\
\hline & A2B1C2(600g) & $9.961 \mathrm{E}-02$ & $1.185 \mathrm{E}-02$ & 2.088E-02 & $1.5 \mathrm{E}-02$ & 3.174E-03 & not detected \\
\hline & A2B3C1(620g) & 0.1433 & $1.474 \mathrm{E}-02$ & 2.357E-02 & 2.7E-02 & $9.19 \mathrm{E}-04$ & not detected \\
\hline & A2B3C1(600g) & 0.1409 & 1.963E-02 & 2.049E-02 & $2.4 \mathrm{E}-02$ & 8.01E-04 & not detected \\
\hline
\end{tabular}

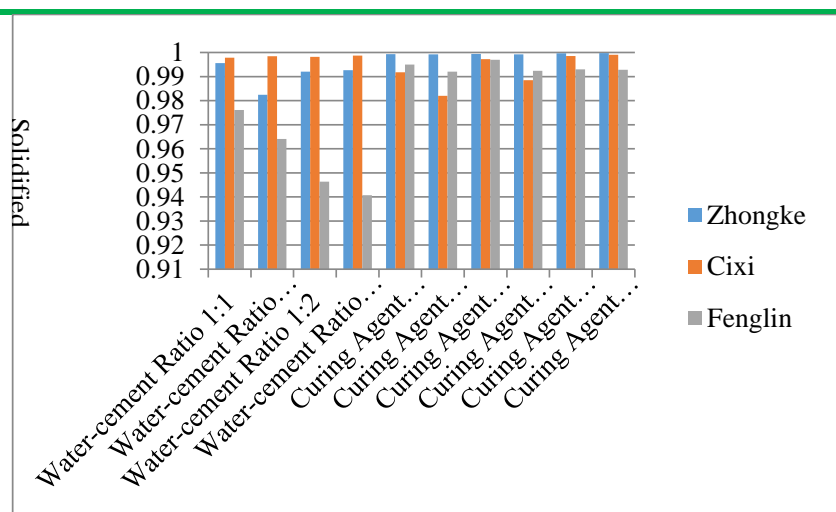

Fig. 1 The curing rate of cement and new curing agent for $\mathrm{Cr}$

The curing rate of cement and new curing agent for metal $\mathrm{Cu}$ can be seen in Fig. 2. From Fig. 2, it can be known that the new curing agent's curing effect is preferable and better than cement, especially for CiXi and FengLin's fly ash. When using cement, the curing effect is poor at the mix cement:ash is $1: 1$ and $1: 1.5$. For example, the curing rate is only 0.996347 at the mix cement:ash=1:1.5of FengLin.

Fig. 3 shows the curing rate of cement and new curing agent for metal $\mathrm{Pb}$. The new curing agent's curing effect is goodand superior to cement. Such as the curing rate are separately 0.9885, 0.99694 and 0.986223 when at the mix cement:ash are $1: 1$ of CiXi, 1:1 of FengLin and 1:1.5 of FengLin, which are all worse than the new curing agent's. 


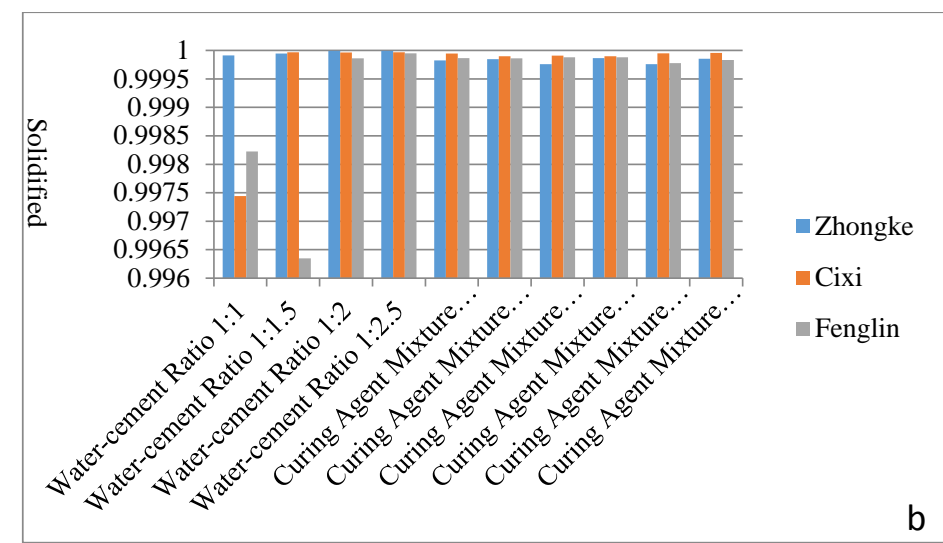

Fig. 2 The curing rate of cement and new curing agent for $\mathrm{Cu}$

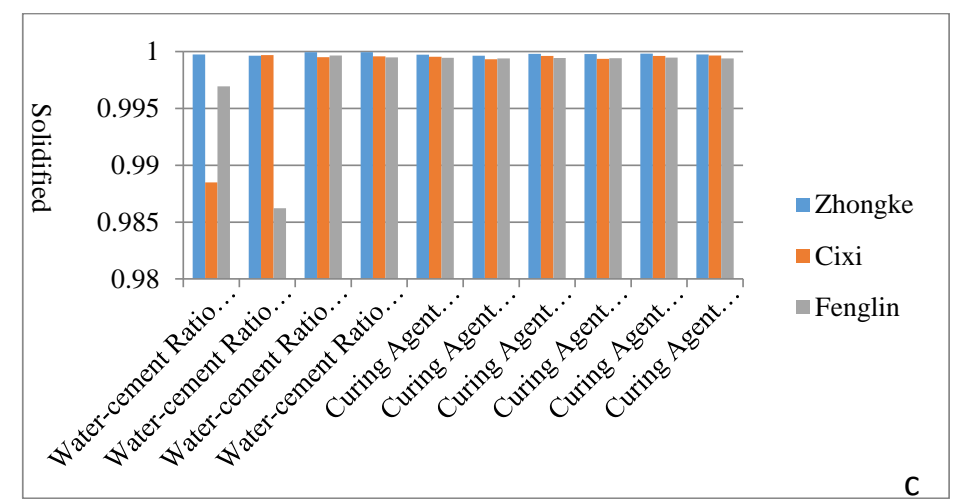

Fig. 3 The curing rate of cement and new curing agent for $\mathrm{Pb}$

Fig. 4 shows the curing rate of cement and new curing agent for metal Zn. Fig. 4 indicates that the curing effect of new curing agent is satisfying and better than cement.The curing rates are too low at the mix cement:ash are 1:1 of CiXi, 1:1 of FengLin and 1:1.5 of FengLin. By contrast, the new curing agent's solidification effect is balanced.

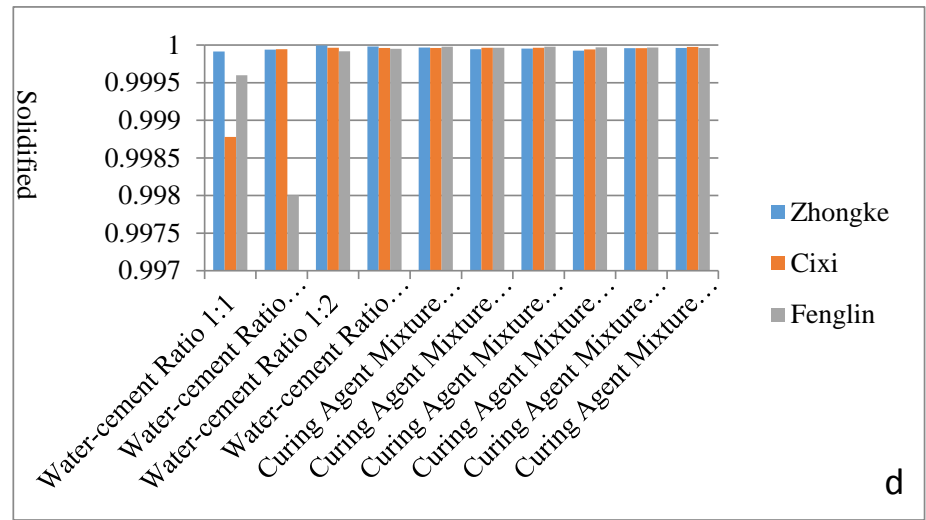

Fig. 4 The curing rate of cement and new curing agent for $\mathrm{Zn}$

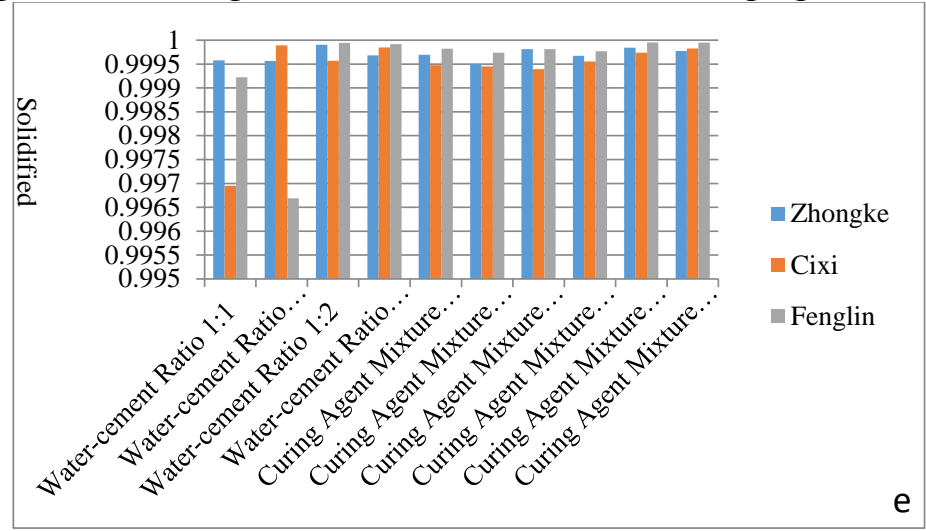

Fig. 5 The curing rate of cement and new curing agent for $\mathrm{Cd}$ 


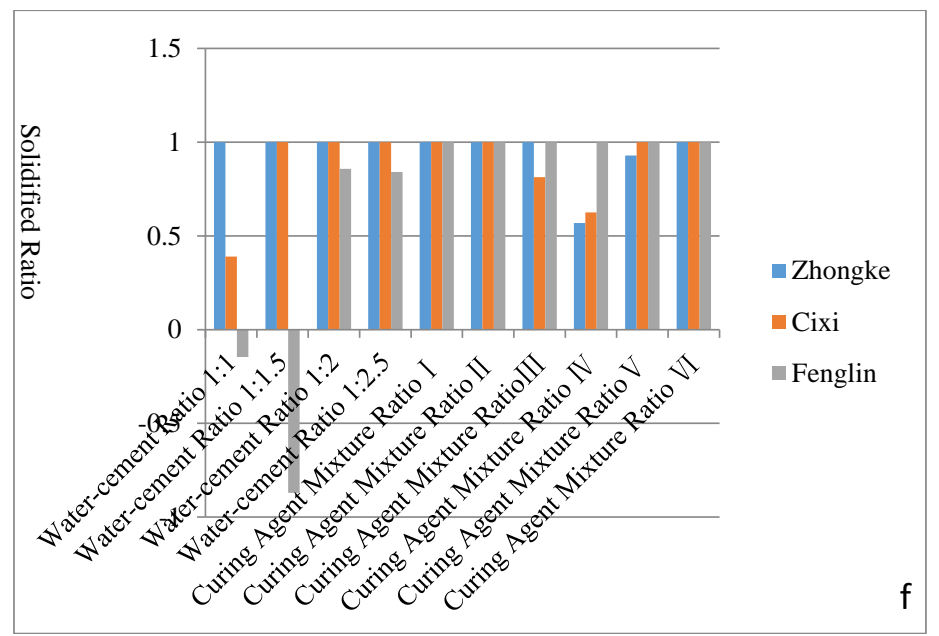

Fig. 6 The curing rate of cement and new curing agent for $\mathrm{Ni}$

The curing rate of cement and new curing agent for metal Cd can be seen in Fig. 5. The new curing agent's curing effect is goodand superior to cement. The curing rate are separately 0.996952 and 0.999223 when at the mix cement:ash are 1:1 of CiXi and 1:1.5 of FengLin, which are both worse than the new curing agent's. As the same, the new curing agent's solidification effect is balanced.

Fig. 6 shows the curing rate of cement and new curing agent for metal Ni. It can be known that the curing agent's curing effect is much better than cement's for FengLin's ash. An opposite effectoccurs that metal Ni detected increases instead of decreasing when solidified by cement. The reason may be that the cement causes compound which contains Ni resolving and producing more soluble Ni ions in fly ash. However, the heavy metal curing rate of fly ash solidified by the new curing agent is 1, which means entirely cured. Cement's curing effect is good for ZhongKe's ash. But for CiXi's, the cement's curing rate is only 0.39 at the mix cement:ash=1:1, and the new curing agent's curing rates are just 0.625 and 0.813 at the mixA1B2C2(620g) and A1B2C2(600g)correspondingly. Their effect are not good. Although new curing agent's effect is superior to cement, in order to achieve a better effect, the new curing agent at the suitable proportion should be chosen.

In conclusion, the new curing agent's curing effect is much better than cement's for heavy metals. But the mix proportion of curing agent should be considered, the proportion with good curing effect should be chosen preferentially. In addition, the new curing agent numbered 5 and 6 have preferable curing effect for all heavy metals. Thenew curing agentnumbered 5 and 6 is A3B1C3(620g), A3B1C3(600g) for ZhongKe; A1B3C3(620g), A1B3C3(600g) for CiXi and A2B3C1(620g), A2B3C1(600g) for FengLin.

\section{The Environment Security of Consolidation's Application to Asphalt}

\subsection{Leaching Toxicity Test of MSWI Fly Ash Consolidation}

According to the previous research [7], it was found that the asphalt mixture added the MSWI fly ash with appropriate proportion has good physical and mechanical properties, high temperature stability and water stability. In order to further understand the safety of the material, we have carried out the leaching toxicity test of the asphalt mixture, shown in table 5.

From experiment results, it is found that the minimum leaching content of heavy metals though

the horizontal vibration method is less than the value requested in the "Solid Waste discharge standard" and "Integrated wastewater discharge Standard", however, the leaching content of heavy metals though the rotating-shaking method from the American EPA is over that requested in the

"Solid Waste discharge standard" and "Integrated wastewater discharge Standard". At the same time as you can see, the leaching toxicity of MSWI fly ash without consolidate is far more than the value required in the "Solid Waste discharge standard" and "Integrated wastewater discharge Standard". By adopting consolidation agent to consolidate heavy metal ions in the MSWI fly ash, a good effect has achieved, the consolidation ratio of heavy metal ions is generally over $98 \%$, even arrives at $100 \%$. 
Table 5 Leaching toxicity of heavy metals in MSWI fly ash consolidation

\begin{tabular}{ccccccc}
\hline Items & $\mathrm{Pb}$ & $\mathrm{Zn}$ & $\mathrm{Cd}$ & $\mathrm{Cr}$ & $\mathrm{Cu}$ & $\mathrm{Ni}$ \\
\hline $\begin{array}{c}\text { Solid Wastedischarge standard } \\
\quad \text { Integrated wastewater }\end{array}$ & 3 & 50 & 0.3 & 10 & 50 & 1.0 \\
$\begin{array}{c}\text { discharge Standard } \\
\text { minimumleaching content of }\end{array}$ & 1.0 & 5.0 & 0.1 & 1.5 & 2.0 & 1.0 \\
$\begin{array}{c}\text { MSWI fly ash consolidation } \\
\text { after 56 days' immersion }\end{array}$ & 0.06 & 0.10 & 0.02 & 0.02 & 1.60 & Not detected \\
$\begin{array}{c}\text { maximum leaching content of } \\
\text { MSWI fly ash consolidation } \\
\text { after 56 days' immersion }\end{array}$ & 0.38 & 0.19 & 0.06 & 0.02 & 0.08 & Not detected \\
$\begin{array}{c}\text { leaching content of MSWI fly } \\
\text { ash without consolidate }\end{array}$ & 22.79 & 86.42 & 2.04 & 7.09 & 7.21 & 1.49 \\
$\quad$\begin{tabular}{c} 
Consolidation ratio (\%) \\
\hline
\end{tabular} & 98.33 & 99.78 & 97.06 & 99.72 & 98.89 & 100 \\
\hline
\end{tabular}

\subsection{Mechanism Analysis on Stability of Heavy Metals inAsphalt Mixture containing the MSWI Fly Ash}

The consolidation's existential state of heavy metals in asphalt mixture can be analyzed by multistage extract, so as to determine the long-term stability of heavy metals' curing. Table 6 indicates the result of multistage extract experiment.

Table 6 the result of multistage extract(\%)

\begin{tabular}{cccccccc}
\hline & $\begin{array}{c}\text { water-soluble } \\
\text { state }\end{array}$ & $\begin{array}{c}\text { Ca ion } \\
\text { exchange } \\
\text { state }\end{array}$ & $\begin{array}{c}\text { acid-soluble } \\
\text { state }\end{array}$ & $\begin{array}{c}\text { Organic } \\
\text { combined } \\
\text { state }\end{array}$ & $\begin{array}{c}\text { Uncrystalline } \\
\text { iron oxide } \\
\text { state }\end{array}$ & $\begin{array}{c}\text { Crystalline } \\
\text { iron oxide } \\
\text { state }\end{array}$ & $\begin{array}{c}\text { residual } \\
\text { form }\end{array}$ \\
\hline $\mathrm{Pb}$ & 1.60 & 2.21 & 11.69 & 1.72 & 16.85 & 50.43 & 15.50 \\
$\mathrm{Zn}$ & 0.99 & 1.28 & 2.91 & 1.92 & 38.91 & 42.80 & 11.20 \\
$\mathrm{Cr}$ & 3.69 & 2.30 & 5.07 & 11.52 & 28.57 & 7.83 & 41.01 \\
$\mathrm{Cd}$ & 8.00 & 6.00 & 26.00 & 6.00 & 18.00 & 16.00 & 20.00 \\
\hline
\end{tabular}

The distribution pattern of heavy metal ions such asPb, Zn, Cd and Crin asphalt mixture containing the MSWI fly ash is shown in this table. $\mathrm{Pb}$ acid-soluble state accounted for $11.69 \%$, which belongs to carbonate and hydroxide. It is easy to leaching in acid medium, but it will not exceed standard because it's content is less than $12 \%$. Pbuncrystalline and crystalline iron oxide state accounted for $16.85 \%$ and $50.43 \%$ separately, which belong to sulfate, elementary substance and chromate etc. Heavy metal ions are difficult to leaching under these kinds of form.Residual form accounted for $15.5 \%$, which belongs to silicat, alum inosilicate, elementary substance and oxide. Under this kind of form, heavy metals have no possibility to leaching. More than 85 percent of $\mathrm{Zn}$, Candor ions in consolidation belong to organic combined state, crystalline iron oxide state, crystalline iron oxide state and residual form, which indicates that physical-chemical reaction caused by curing agent makes heavy metal ions react into sulfate, elementary substance, chromate, silicate, alum inosilicate and oxide which are stable mineral facies. And in asphalt mixture, heavy metals are too hard to leaching. So, MSWI fly ash consolidation can be applied to engineering safely.

\section{Conclusion}

1. The new curing agent's curing effect is much better than cement's for heavy metals.

2. Certain mix proportion is determined for certain kind of fly ash.

3.MSWI fly ash consolidation can be applied to engineering safely.

\section{Acknowledgments}

This work is Ningbo Social Development Research Project, "Solidification Technology of Municipal Solid Waste Incineration Fly Ash and Its Utilization" supported by Ningbo Science and Technology Projects under grant 2011C50018. 


\section{Reference}

[1] Wang Yan. Dioxin and human health[J]. Chinese Journal of Public Health Engineering, 2003, 2(4): 246-250.

[2] Luo Zhong-tao, Xiao Yu-ling, Yang Jiu-jun. The research overview of solidification and stabilization of toxic heavy metals in MSWI fly ash[J]. Environmental Pollution \& Control, 2012, 34:58-62. DOI:doi:10.3969/j.issn.1001-3865.2012.08.013.

[3] Yuan Lin, Shi Hui-sheng. The migration of heavy metals in MSWI fly ash and cement solidification's mechanism[J]. Journal of Building Materials, 2004, 7:76-80. DOI:doi:10.3969/j.issn.1007-9629.2004.01.014.

[4] Ma Bao-guo, Huang Xiang, Li Xiang-guo. The research of preparation of cement clinker by MSWI fly ash[J]. Journal of wuhan university of technology, 2009:51-54.

[5] JiangJian-guo, Zhao Zheng-zheng, Wang Jun. The technology of MSWI fly ash's cured by cement[J] Acta Scientiae Circumstantiae, 26:230-235. DOI:doi:10.3321/j.issn:0253-2468.2006.02.011.

[6] Huang Jian-huan. The leaching of heavy metals in MSWI fly ash and cement's solidification[D]. South China University of Technology, 2013.

[7] Shen Jian-sheng, Sun Jia-ying. The pavement performance of asphalt mixture containing sludge drainage consolidation microgrits[J]. Journal of Building Materials, 2013, 16:102-105. DOI:doi:10.3969/j.issn.1007-9629.2013.01.019. 